\title{
Determination of Toxic and Essential Elements in Urine by Inductively Coupled Plasma Mass Spectrometry
}

\author{
DOI: $10.17691 / \mathrm{stm} 2016.8 .3 .14$
}

Received June 10, 2015

G.A. Veikhman, PhD, Leading Researcher, Laboratory of Elemental Analysis Methods";

Senior Lecturer, Department of General and Organic Chemistry²;

o.v. Gilyova, $\mathrm{PhD}$, Leading Chemist, Laboratory of Elemental Analysis Methods";

E.V. Stenno, Head of the Laboratory of Elemental Analysis Methods';

T.S. Ulanova, DSe, Head of the Department of Chemical and Analytical Research Methods';

Professor, Department of Environmental Protection ${ }^{3}$

1 Federal Scientific Center for Medical and Preventive Health Risk Management Technologies, 82 Monastyrskaya St., Perm, 614045, Russian Federation;

2Perm State Pharmaceutical Academy, 2 Polevaya St., Perm, 614000, Russian Federation;

3Perm National Research Polytechnic University, 29a Komsomol'skiy prospekt,

Perm, 614990, Russian Federation

The aim of the investigation was to optimize the conditions of a routine urinalysis by inductively coupled plasma mass spectrometry (ICP-MS) for diagnostic studies.

Materials and Methods. We determined the content of 12 elements (V, Cr, Mn, Ni, Cu, Zn, As, Se, Sr, Cd, Tl, Pb) in the urine of children in Russian industrial region ( $n=57$, mean age being under 6 years) by ICP-MS on a quadrupole mass spectrometer Agilent $7500 \mathrm{cx}$ (Agilent Technologies, USA) with octopole collision/reaction cell according to the methodology developed by MUK 4.1.3230-14.

Results. The arithmetic mean of the elements in the group was $0.72 \mu \mathrm{g} / \mathrm{L}(\mathrm{V}) ; 2.13 \mu \mathrm{g} / \mathrm{L}(\mathrm{Cr}) ; 1.11 \mu \mathrm{g} / \mathrm{L}(\mathrm{Mn}) ; 2.76 \mu \mathrm{g} / \mathrm{L}(\mathrm{Ni}) ; 26.67 \mu \mathrm{g} / \mathrm{L}$ (Cu); $482.1 \mu \mathrm{g} / \mathrm{L}(\mathrm{Zn}) ; 10.09 \mu \mathrm{g} / \mathrm{L}$ (As); $32.84 \mu \mathrm{g} / \mathrm{L}$ (Se); 1,275.35 $\mu \mathrm{g} / \mathrm{L}(\mathrm{Sr}) ; 0.122 \mu \mathrm{g} / \mathrm{L}$ (Cd); $1.16 \mu \mathrm{g} / \mathrm{L}$ (TI); $2.16 \mu \mathrm{g} / \mathrm{L}$ (Pb). The urine samples were directly analyzed after diluting $1: 10$ by $1 \%$ nitric acid solution. The findings accuracy was confirmed by comparing with the values of standard urine samples performed by SERONORM ${ }^{\mathrm{TM}}$ urine.

Conclusion. The proposed easy method to determine the essential and toxic elements in urine using a mass spectrometer Agilent $7500 \mathrm{cx}$ with octopole collision/reaction cell can be recommended for diagnostic and screening tests in clinical settings.

Key words: mass spectrometry with octopole collision/reaction cell; ICP-MS; collision/reaction cell; essential and toxic elements; urinalysis.

The problem of establishing the relationship between environmental exposure and health status of the population is one of the most urgent and challenging in modern preventive medicine. The application of modern medical technologies for rehabilitation and treatment of the population under anthropogenic stress requires new rapid tests to determine the content of chemical compounds and elements in biological media. According to research associates [1], electrothermal atomization atomic absorption spectroscopy (ETA-AAS) with Zeeman background correction and inductively coupled plasma mass spectrometry (ICP-MS) are the most promising techniques used to study biological fluids without prior sample deterioration. However, the capability to determine a great number of elements in one sample, low detection limits, high reproducibility, a wide range of detectable concentrations, low consumption of substances sampled, high efficiency provide greater prospects when biomedia are studied by ICP-MS.
Normative and methodological base of Russia has methodological instructions on determining chemical elements in biological media: MUK 4.1.1483-03 [2], which are advisory in nature. They have been elaborated on the basis of ICP-MS, however, they fail to meet current standardization requirements and metrological certification, and do not take into consideration particular conditions when samples are prepared, device setting parameters that causes difficulties in using the instructions in laboratory practice.

In the elemental analysis laboratory of Federal Scientific Center for Medical and Preventive Health Risk Management Technologies (Perm) there were developed and introduced the techniques of simultaneous determination of 12 chemical elements (vanadium, chrome, manganese, nickel, cuprum, zinc, selenium, strontium, thallium, lead, cadmium, arsenic) in biomedia [3-6]. The techniques (MUK 4.1.3161-14, MUK 4.1.3230-14) are registered in Federal information

For contacts: Galina A. Veikhman, e-mail: veikhman_ga@mail.ru 


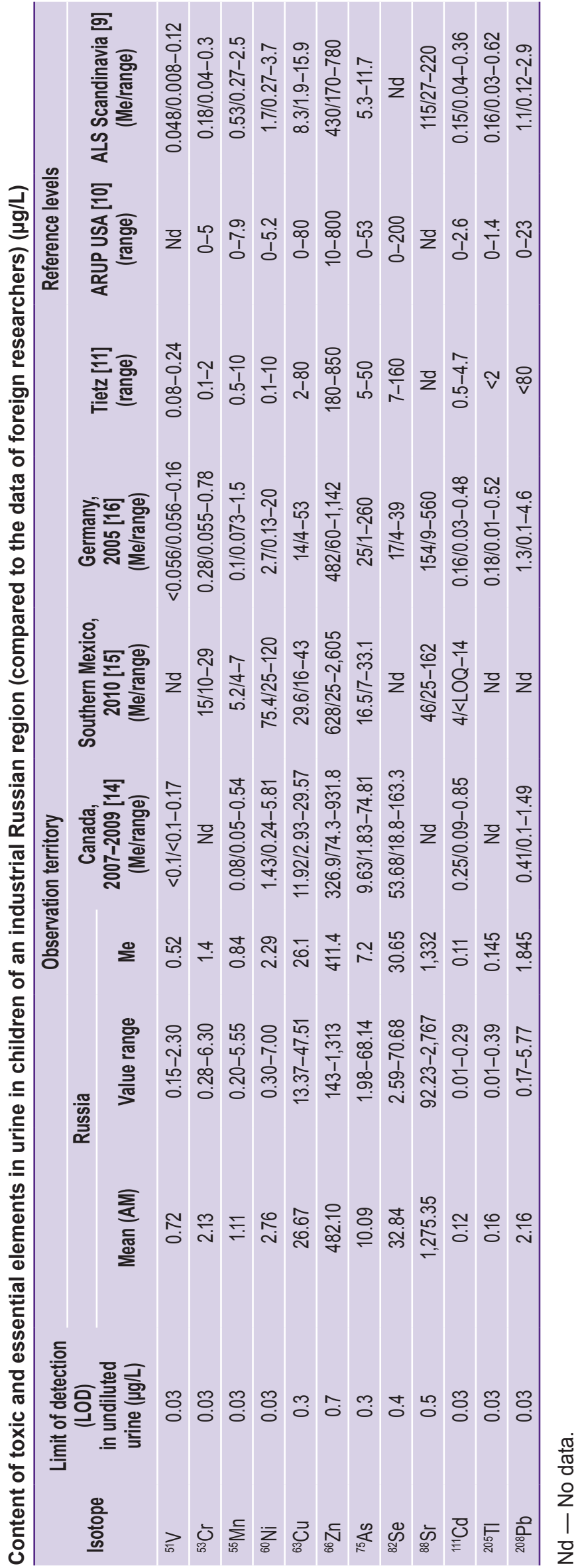

measurement assurance fund (FR.1.31.2014.17064) [7] and used in routine clinical diagnosis of health situation in population living in territories with negative impact of the environment, as well as for control after rehabilitation treatment in hospital environment.

Our choice of elements to be determined in biomedia is well-considered. The recommended diagnostic elements in urine are $\mathrm{Cu}, \mathrm{Zn}, \mathrm{Mn}, \mathrm{Ni}$, $\mathrm{Pb}, \mathrm{Cr}, \mathrm{As}, \mathrm{Cd}, \mathrm{Tl}$ and $\mathrm{V}[1,8]$. In addition, we think it necessary to control $\mathrm{Sr}$ content in biomedia, since within Perm territory there are regions with high concentration of strontium in drinking water. It should be noted that the data on concentration of some the above mentioned elements in urine reported by different researchers are conflicting. The Table shows the reference values of the elements in urine calculated in diagnostic laboratories ALS Scandinavia [9], ARUP USA [10], and represented in well-known Tietz clinical guide to laboratory tests [11]. The first use the data of Rodushkin and Ödman obtained by ICP-MS [12], and the other refers to Komaromy-Hiller et al. [13]. There are differences in allowable levels for $\mathrm{Cr}, \mathrm{Mn}, \mathrm{Cu}, \mathrm{Cd}, \mathrm{Pb}$.

Tietz presents reference levels determined by flame atomic absorption spectrometry and atomic absorption spectrometry with electrothermal atomisation (FAAS and ETA-AAS), which are close to those under discussion only for $\mathrm{Cu}, \mathrm{Zn}$, As. Moreover, the limits of detection (LOD) of the mentioned techniques are known to be able to differ by several orders [1].

Due to the existing problem we aimed at estimating the correctness of findings using the developed technique when a number of microelements were simultaneously determined in urine samples using IPC-MS in children living in industrial regions.

The aim of the investigation was to optimize the conditions of a routine urinalysis by inductively coupled plasma mass spectrometry for diagnostic studies.

Materials and Methods. From analytical point of view, biological fluids are difficult to analyze not only due to a very low content of the most determined microelements, but also due to their complex matrix composition. The most common noninvasive object of biomedia research is urine. Urine biological matrix due to renal filtration is free from plasma proteins, lipids and other compounds with large molecular mass that simplifies a sample preparation process. At the same time, the key problem in determining the elements in urine is its high salt composition (chlorides, sulfates and phosphates) resulting in a significant impact of matrix effect and beat interference. The use of octopole reaction/collision cell enables to minimize the matrix effect of urine salt composition and determine such complex elements as $\mathrm{Cr}$, As, Se and V.

$\mathrm{V}, \mathrm{Cr}, \mathrm{Mn}, \mathrm{Ni}, \mathrm{Cu}, \mathrm{Zn}, \mathrm{As}, \mathrm{Se}, \mathrm{Sr}, \mathrm{Cd}, \mathrm{Tl}, \mathrm{Pb}$ in 


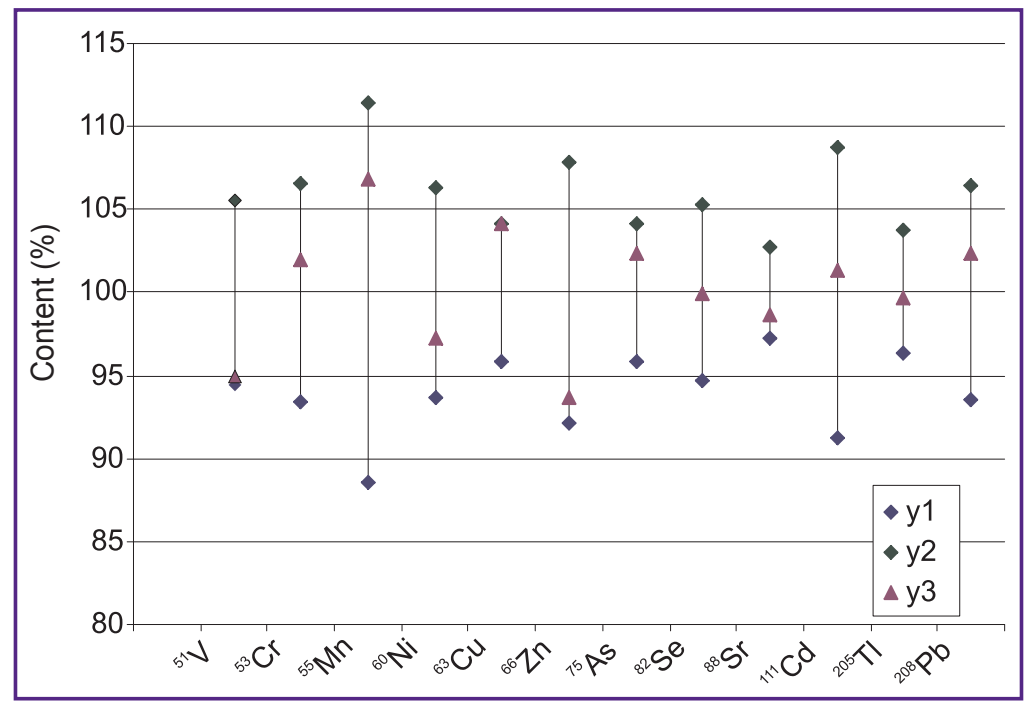

Results of microelement determination in percentage in regard to certified values in SeronormTM urine samples $(n=12)$ : $y 1$ minimal certified level (\%); y2 - maximal certified level (\%); y3 - detected (\%)

urine samples were quantitatively determined on a quadrupole mass spectrometer with inductively coupled plasma Agilent 7500cx (Agilent Technologies, USA) with octopole reaction/collision cell. Helium was used as a reaction gas to determine all the elements. Helium flow rate of $5.0 \mathrm{ml} / \mathrm{min}$ was experimentally stated that enabled to reduce significantly the polyatomic overlay with saving a high sensitivity level. The capacity of high-frequency signal was $1,550 \mathrm{~W}$. For sample administration we used a double-pass Scott-type spray chamber. The temperature of a spray chamber was $2.0^{\circ} \mathrm{C}$. The sample feed rate in the spray chamber was $0.4 \mathrm{ml} / \mathrm{min}$. The distance from a burner to a selecting cone was $9 \mathrm{~mm}$. The detector rate was $\leq 100 \mu \mathrm{s}$ per 1 ion. For tuning we used the solution of ${ }^{7} \mathrm{Li},{ }^{59} \mathrm{Co},{ }^{89} \mathrm{Y}$ and ${ }^{205} \mathrm{TI}$ in $2 \%$ of $\mathrm{HNO}_{3}$ with the concentration of $1 \mu \mathrm{g} / \mathrm{L}$ for each element (Tuning Solution, USA). The ratio ${ }^{140} \mathrm{Ce}^{16} \mathrm{O}^{+} /{ }^{140} \mathrm{Ce}^{+}$was $<1 \%$, and for ${ }^{140} \mathrm{Ce}^{2+} / 140 \mathrm{Ce}^{+}$it being $<3 \%$. High purity liquid argon 99.99\% (TU-2114-00500204760-99) was used. The maximum argon flow rate was $20 \mathrm{~L} / \mathrm{min}$, the pressure in the gas supply channel being $700 \pm 20 \mathrm{kPa}, \mathrm{T}_{\text {plasma }}=8,000-10,000 \mathrm{~K}$. The analysis automation was provided by G3160B, Integrated autosampler (Germany). The solution containing 27 elements with concentration of $10 \mathrm{mg} / \mathrm{L}$ in $5 \%$ water solution of $\mathrm{HNO}_{3}$ (Multi-Element Calibration Standard2A; Aligent Technologies, USA) was used as the main standard solution. To prepare calibration solutions and samples, we used especially pure $\mathrm{HNO}_{3}$ (Sigma-Aldrich, USA).

The concentrations of calibration solutions to determine $\mathrm{Cd}$ and TI were $0.0 ; 0.1 ; 0.5 ; 1.0 \mu \mathrm{g} / \mathrm{L}$; for $\mathrm{Mn}$, $\mathrm{Ni}, \mathrm{Cr}, \mathrm{V}$, Se, Cu: 0.0; 0.1; 0.5; 1.0; $5.0 \mu \mathrm{g} / \mathrm{L}$; for As, Sr, Zn: $0.0 ; 1.0 ; 5.0 ; 10.0 ; 50.0 \mu \mathrm{g} / \mathrm{L}$. The complex standard solution ${ }^{209} \mathrm{Bi},{ }^{73} \mathrm{Ge},{ }^{115} \mathrm{In},{ }^{6} \mathrm{Li},{ }^{45} \mathrm{Sc},{ }^{159} \mathrm{~Tb},{ }^{89} \mathrm{Yc}$ with concentration of $10 \mathrm{mg} / \mathrm{L}$ in $5 \%$ water solution of $\mathrm{HNO}_{3}$ (Internal Standard Mix; Aligent Technologies, USA) was used to prepare the internal standard (IS) solutions.
${ }^{159} \mathrm{~Tb}$ was used as an internal standard for $\mathrm{Pb}$ and $\mathrm{TI}$ determination, ${ }^{115}$ In was used to determine $\mathrm{Cd}$, and for other elements ${ }^{72} \mathrm{Ge}$ was used due to the proximity of their ionization potentials and atomic mass. All solutions were diluted with deionized water with specific resistivity of $18.2 \mathrm{MOm} \cdot \mathrm{cm}$ purified in the system Milli-Q Integral (Millipore SAS, France). A blank sample was prepared in the same manner as a work sample.

Ultrasonic cleaner Elmasonic S $100 \mathrm{H}$ (Germany) was used to prepare the glassware made of glass, Teflon, polypropylene for analysis. The dishes were incubated for $20 \mathrm{~min}$ in bidistilled water at $55^{\circ} \mathrm{C}$, then for $20 \mathrm{~min}$ in an aqueous nitric acid solution $(1: 5)$ at $55^{\circ} \mathrm{C}$ followed by deionization in water for $20 \mathrm{~min}$ at $55^{\circ} \mathrm{C}$.

To control the accuracy of the analysis results we used standard urine samples Seronorm ${ }^{\mathrm{TM}}$ urine (LOT 0511545; Sero AS, Norway). The preparation for the analysis of standard urine samples was similar to that of real samples. Control samples were analyzed after every fifth real sample.

The Figure shows the results of microelements determined in percentage in relation to the certified values $(\mathrm{n}=12)$. The concentrations of $\mathrm{Cr}, \mathrm{Mn}, \mathrm{Cu}, \mathrm{As}, \mathrm{Cd}$ and $\mathrm{Pb}$ were found to be above $100 \%$, the error detection being 1.5-7.0\%. V, Ni, Zn, and Sr showed concentrations below $100 \%$. The error of their determination was in the range from 2 to $7 \%$ and corresponded to the certified values. The contents of Se and TI were found as $100 \%$ level.

The findings of investigations enable to elaborate the technique for simultaneous determination of 12 elements in urine (MUK 4.1.3230-14) [7]. The technique is different from the existing methodological guidelines 4.1.148303 [2] in that it has a proven procedure of sample preparation to minimize matrix effects, the selection of internal standards for each element being determined, the use of a collision/reaction cell with helium to correct polyatomic interferences. The Table shows the limits of determination (LOD) in undiluted urine. 
The content of V, Cr, Mn, Ni, Cu, Zn, As, Se, Sr, Cd, $\mathrm{TI}, \mathrm{Pb}$ using the developed technique was determined in 57 urine samples of children from an industrial Russian region, their age being 3-7 years, among them there were $47 \%$ girls and $53 \%$ boys. The study groups included children with no congenital pathology, organic and infectious diseases of the central nervous system in their past history. Biomedical studies comply with the declaration of Helsinki (adopted in June, 1964 (Helsinki, Finland) and revised in October, 2000 (Edinburg, Scotland)). All legal representatives of children involved in the sampling gave their written informed consent to voluntary participation in the study.

Sampling of morning urine was performed in screwcapped sterile $125 \mathrm{ml}$ polypropylene containers (FL Medical S.r.l., Italy). The urine samples were directly analyzed after diluting $1: 10$ with $1 \%$ solution of nitric acid: $4.45 \mathrm{ml}$ of $1 \%$ water solution of $\mathrm{HNO}_{3}$ and $0.05 \mathrm{ml}$ of the internal standard solution was added to $0.5 \mathrm{ml}$ of urine.

The findings of urine samples were represented as arithmetic mean (AM), median (Me), as well as the ranges of values in a group. The median appeared to be close to arithmetic mean only for $\mathrm{Cu}$ and $\mathrm{Cd}$. For comparison the Table shows the known urinary findings of children in Canada (aged 6-11 years) [14], Southern Mexico (aged 6-11 years) [15] and Germany (aged 2-17 years) [16].

Results and Discussion. The content of elements in urine of children living on the observation area does not exceed the approved reference levels with the exception of vanadium and strontium exceeding the median 10 times as much. High strontium concentration in urine is associated with the proximity of to celestite ore deposit containing up to $20 \%$ of strontium sulfate. Vanadium content compared to that in Canadian children showed fivefold increase of median, manganese content was ten times as large, nickel and cuprum: twice as large, and plumbum three times as large. Arsenic and cadmium contents were higher in Canadian children. The contents of vanadium, chromium, manganese, cuprum, strontium, and lead according to the arithmetic mean exceeded those found in children in Germany. The content of chromium, manganese, nickel, zinc, arsenic and cadmium in the urine of children living in a mining district of Southern Mexico (inductively coupled plasma atomic emission spectroscopy method) exceeded the levels reported in our study.

The integrated assessment of the health status of children of the study group revealed that only $1.7 \%$ of the children could be referred to apparently healthy children. One third of preschool children had chronic pathology in the state of compensation and sub-compensation $(31.1 \%)$. One in five children in the study group had the deviation from mean growth indices, 33.6\% children had disharmonic physical development. Gastrointestinal diseases (half of the examined children) and nervous system disorders (one in five children) were considered as the main diagnoses. Ultrasound findings of the liver, gallbladder and biliary tract of the children revealed the increase of the linear dimensions of the right lobe of the liver and reactive changes of hepatic parenchyma in one in eight children. Musculoskeletal diseases combined with high strontium level in urine prevailed in the structure of comorbidities. Musculoskeletal disorders were found in $62.9 \%$ children and were represented as postural disorders (84.6\%) and accelerated bone maturation $(27 \%)$.

Thus, according to the determination findings of toxic and essential elements in urine by ICP-MS using the developed technique, the present territory can be assessed as unfavorable ecologic hygienic situation.

Conclusion. The proposed easy method to determine the essential and toxic elements in urine using a mass spectrometer Agilent $7500 \mathrm{cx}$ with octopole collision/ reaction cell can be recommended for diagnostic and screening tests in clinical settings.

Study Funding and Conflicts of Interest. The study was not funded by any sources, and the authors have no conflicts of interest related to the present study.

\section{References}

1. Ivanenko N.B., Ganeev A.A., Solovyev N.D., Moskvin L.N. Determination of trace elements in biological fluids. J Anal Chem 2011; 66(9): 784-799, http://dx.doi. org/10.1134/s1061934811090036.

2. MUK 4.1.1483-03. Opredelenie soderzhaniya khimicheskikh elementov $v$ diagnostiruemykh biosubstratakh, preparatakh i biologicheski aktivnykh dobavkakh metodom mass-spektrometrii $s$ induktivno svyazannoy argonovoy plazmoy [MUK 4.1.1483-03. Determination of the content of chemical elements in diagnosable biosubstrates, preparations and biologically active additives using inductively coupled argon plasma mass-spectrometry]. Moscow; 2003.

3. Veikhman G.A., Ulanova T.S., Stenno E.V., Gileva O.V., Bakanina M.A. Evaluating chemical exposure in vannadium iron alloys production. Meditsina truda $i$ promyshlennaya ekologiya 2011; 11: 20-24.

4. Zaytseva N.V., Ulanova T.S., Sinitsyna O.O., Gileva Olga V. Methodical ware for the hygienic risk assessment of vanadium exposure to the children's health. Gigiena i sanitariya 2014; 93(4): 115-119.

5. Ulanova T.S., Stenno E.V., Veykhman G.A., Gileva O.V., Bakanina M.A. The estimation of the contents of toxic trace elements in engineering plant workers blood. Metody i ob"ekty khimicheskogo analiza 2013; 8(2): 72-75.

6. Ulanova T.S., Gileva O.V., Stenno E.V., Veikhman G.A. Peculiarities of vanadium determination in whole blood by ICPMS. Biomeditsinskaya khimiya 2014; 60(1): 109-114, http:// dx.doi.org/10.18097/pbmc20146001109.

7. MUK 4.1.3230-14. Izmerenie massovykh kontsentratsiy khimicheskikh elementov $v$ biosredakh (krov', mocha) metodom mass-spektrometrii $s$ induktivno svyazannoy plazmoy [Measurement of mass concentrations of chemical elements in biomedia (blood, urine) by inductively coupled plasma mass-spectrometry]. Moscow; 2015. 
8. Kaletina N.I. Toksikologicheskaya khimiya. Metabolizm $i$ analiz toksikantov [Toxicological chemistry. Metabolism and analysis of toxicants]. Moscow: GEOTAR-Media; 2008; $1016 \mathrm{p}$.

9. Reference data-Biomonitoring. Trace elements in human biological material. ALS Scandinavia. URL: http://www. alsglobal.se.

10. ARUP Users Guide. Salt Lake City, UT: Associated Regional\& University Pathologists; 2004-2005.

11. Tietz clinical guide to laboratory tests. USA: W.B. Saunders Company; 2006.

12. Rodushkin I., Ödman F. Application of inductively coupled plasma sector field mass spectrometry for elemental analysis of urine. J Trace Elem Med Biol 2001; 14(4): 241-247, http://dx.doi.org/10.1016/s0946-672x(01)80010-9.

13. Komaromy-Hiller G., Ash K.O., Costa R., Howerton K. Comparison of representative ranges based on U.S. patient population and literature reference intervals for urinary trace elements. Clin Chim Acta 2000; 296(1-2): 71-90, http://dx.doi. org/10.1016/s0009-8981(00)00205-9.

14. Report on human biomonitoring of environmental chemicals in Canada. Results of the Canadian Health Measures Survey Cycle 1 (2007-2009). URL: http://www.hc-sc.gc.ca/ewhsemt/pubs/contaminants/chms-ecms/index-eng.php.

15. Moreno M.E., Acosta-Saavedra L.C., MezaFigueroa D., Vera E., Cebrian M.E., Ostrosky-Wegman P., Calderon-Aranda E.S. Biomonitoring of metal in children living in a mine tailings zone in Southern Mexico: a pilot study. Int J Hyg Environ Health 2010; 213(4): 252-258, http://dx.doi. org/10.1016/j.ijheh.2010.03.005.

16. Heitland P., Köster H.D. Biomonitoring of 30 trace elements in urine of children and adults by ICP-MS. Clin Chim Acta 2006; 365(1-2): 310-318, http://dx.doi.org/10.1016/j. cca.2005.09.013. 